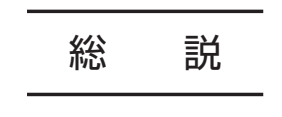

\title{
伝統発酵にみる微生物の共生と進化
}

\author{
森永 康 * 、平山 悟、古川 壮一
}

日本大学生物資源科学部食品生命学科

\begin{abstract}
伝統発酵食品福山酢は、その発醉過程に、麹菌、酵母、乳酸菌、酢酸菌が関与し、糖化、嫌気的アル コール発酵と好気的酢酸発酔が自然に進行する。それは東アジアで生まれた最も原始的な発酵様式であ り、自然環境で起こっている炭水化物代謝を模したとも言えるものである。我々は、福山酢の製造工程 から分離した乳酸菌と酵母及び酢酸菌の異種間相互作用を研究することを目的として、共培養系でのバ イオフィルム形成について検討してきた。その結果、乳酸菌と酵母が共存すると細胞同士の接着により 両細胞が組み込まれた特異な複合バイオフィルムが培養容器底部の固液界面に形成されることや、乳酸 菌と酢酸菌が共存すると培養液の気液界面に形成される酢酸菌のバイオフィルム（ペリクル）が顕著に 増加することを見出した。さらに詳細に相互作用を調べてみると、これら 3 種の発醭微生物の共存系は、 それぞれの菌が機能分担することで、栄養欠そや酸化ストレス、外敵侵入などのさまざまな生存リスク に対応可能なきわめて巧妙な共生系であることが分かってきた。本稿では、こうした伝統発酵に見出し た発酔微生物の共生系の特徵について、我々の成果を中心に紹介し、そこからうかがい知ることができ る発酵微生物の進化についても論じてみたい。
\end{abstract}

Key words : Yeast, Lactic acid bacteria, Acetic acid bacteria, Biofilm, Symbiosis

1.はじめに

多くの伝統発䣲食品に微生物が共存していることは良く 知られている ${ }^{1-10)}$ 。表 1 にその代表例を示した。いずれも 馴染みの発酵食品だが、酵母と乳酸菌が必ず共存している。 酵母が主役で乳酸菌が脇役の場合もあるし、乳酸菌が主役 として働いている場合もある。前者としては清酒、ワイン、 ランビックビールなどのアルコール飲料、後者としては漬 物や発酵乳などがある。一方、酰酸菌が主役の伝統発酵食 品は食酢である。糖を含む原料を醅母の嫌気発䣲によって 一旦アルコールに変換した後に、酢酸菌で好気的に酢酸に 変換するのが伝統製法の基本である ${ }^{11)}$ 。元来アルコール 飲料は、好気的環境に放置すると、酢酸菌によって酢酸に 変換されてしまう。このため、食酢はアルコール飲料とと もに最も古くから人類に利用されてきた発醳食品である。

\footnotetext{
*To whom correspondence should be addressed.

Phone : +81-466-84-3971

Fax : $+81-466-84-3971$

E-mail : morinaga @ brs.nihon-u.ac.jp
}

表 1. 伝統発酵食品にみられる微生物の共存

\begin{tabular}{|c|c|c|c|c|}
\hline 食品 & 敖菌 & 酵母 & 乳酸菌 & 酶酸菌 \\
\hline 清酒 & 0 & 0 & 0 & $*$ \\
\hline ワイン & & 0 & 0 & $*$ \\
\hline 焼酎 & O & $\bigcirc$ & 0 & \\
\hline 泡盛 & 0 & O & 0 & \\
\hline ウイスキー & & 0 & 0 & \\
\hline 食酢 (米酢) & 0 & 0 & 0 & 0 \\
\hline 奨油 & $\bigcirc$ & 0 & 0 & \\
\hline 味噌 & 0 & 0 & 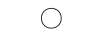 & \\
\hline パン種 & & 0 & $\bigcirc$ & \\
\hline ケフィア & & 0 & 0 & $?$ \\
\hline 豆腐よう & 0 & 0 & 0 & \\
\hline キムチ & & 0 & 0 & \\
\hline
\end{tabular}

*酸敗時に出現

文献10)を改変

このように多くの伝統発酵食品の製造プロセスには酵母、 乳酸菌が共存し、好気的環境ではこれらに加えて酢酸菌が 共存して、物質変換が行われる。こうした物質変換は人類 登場の遥か以前から自然界で起こっていた。我々の先祖は こうした自然の物質变換を巧みに食生活に取り込んでき 
た。このように、伝統発醅の場は微生物変換の模擬的自然 環境とみなすことができる。したがって、伝統発酔微生物 の共生関係を解析することで、発醰に関与する微生物の進 化を探ることは有意義と考えられる。ここでは、我々が研 究対象としてきた福山酢由来の微生物の相互作用解析を例 に、酵母、乳酸菌、酢酸菌の共生と進化について考えてみ たい。

\section{2. 福山酢における微生物の相互作用}

\section{2-1. 福山酢について}

福山酢は、鹿児島県霧島市福山町で約 200 年にわたり製 造されてきた伝統的な米酢である。野外に設置した监の中 に水と蒸米と米鈿を入れ、乾燥させた靝をその上に撒きふ たをする。その後数力月間そのまま静置することにより製 造される。嫌気環境下での糖化とアルコール発酵、撴よび 好気環境下での酢酸発醏の三種類の発酵が、人工的管理を 施すことなく、一つの㽦の中で併行して進行するところに 特徴があり、トリプル発酵と呼ばれている ${ }^{7.12)}$ 。酒造りの 原点に近く、東アジアで生まれた最も原始的な発酔様式の 一つであり、自然環境で起こっている複数の微生物が関与 する炭水化物代謝を模したとも言えるものである。

\section{2-2. 乳酸菌と酵母の相互作用}

我々は、福山酢のもろみから、乳酸菌、酵母拉よび酢酸菌 を分離して、それらの相互作用についてバイオフィルム 形成を指標として調べた。その結果、発酵初期（11日 目）の福山酢から分離した乳酸菌Lactobacillus plantarum ML11-11 (以下 ML11-11) と酔母 Saccharomyces cerevisiae Y11-43（以下 Y11-43）を共培養すると固液界面に付着し て顕著な二菌種複合バイオフィルムを形成することを見出 した（図 1） ${ }^{13)}$ 。乳酸菌 ML11-11 の培養上清を酵母単独培

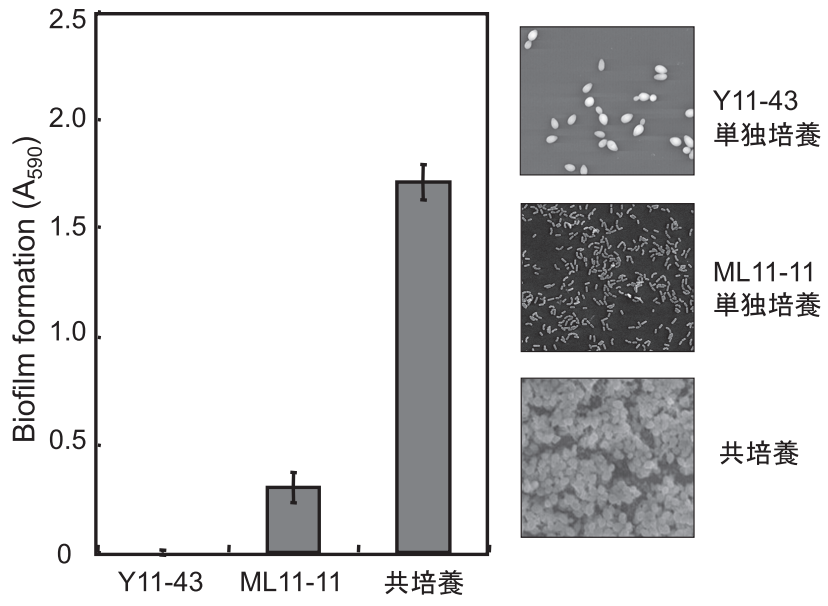

図 1. 乳酸菌と酵母の複合バイオフィルム形成

福山酢分離酵母 Y 11-43 と乳酸菌 ML11-11 の単独培養及び共 培養におけるバイオフィルム形成（左は形成量評価の結果、右は 走査電子顕微鏡による観察結果)。文献 13）功改変
養系に添加してバイオフィルム形成が起こるかどうかを調 べてみた結果、乳酸菌 ML11-11 の培養上清によってバイ オフィルム形成は全く誘起されず、乳酸菌と酵母の細胞同 士の物理的な接触が形成に不可欠なことが判明した ${ }^{13)}$ 。さ らに微細構造を解析した結果、このバイオフィルムの担体 との接触部は乳酸菌で構成され、その上部に乳酸菌と醳母 が㠜集して積み重なった特異な微生物集合体であることが 分かった(図 2 )。以後このバイオフィルムを複合バイオフィ ルムと呼ぶことにした ${ }^{13.14)}$

乳酸菌 ML11-11 は福山酢から分離した酵母 Y11-43だ けでなく、清酒酵母の協会 701 号や実験室酵母の BY4741 などと組み合わせても顕著なバイオフィルムを形成し た ${ }^{13}$. 14)。一方、35 種以上に及ぶ乳酸菌の分離株や保存株 計 250 株以上から乳酸菌 ML11-11 と同様に複合バイオ フィルムを形成する乳酸菌をスクリーニングした結果、新 たに分離株から 2 株 ${ }^{15)}$ 、保存株から 3 株 ${ }^{16)}$ の形成菌を見 出した。乳酸菌 ML11-11 を含め、これまでに見出された 形成菌の 6 株中 5 株はL. plantarumに属していた。その 他の 1 株は Leuconostoc mesenteroides に属していた ${ }^{16)}$ 。 その後、馴れ鮨から分離したLeuconostoc citreum に属す る 3 株がやはり複合バイオフィルム形成能を有しているこ とが分かった ${ }^{17)}$ 。このように、酵母との共培養に扔いて バイオフィルム形成量が増加する現象は L. plantarum や Leuconostoc の一部の菌種にみられる現象である。なお、L plantarum と酵母、Leuconostoc 属菌と酵母との共培養に おいて形成されるバイオフィルムの特性や形成機構の違い については現在詳細を検討中である ${ }^{17)}$

その後、我々は L. plantarum と酵母の複合バイオフィ ルムの形成機序を解析すべく、乳酸菌 ML11-11 と䤉母の 細胞同士の相互作用に関して詳細な解析を進めてきた。そ の結果、再者の細胞を共存させると短時間で共凝集体が形 成されること、その共凝集反応は加熱処理したり、プロテ イナーゼ処理した乳酸菌細胞では起こらないが、加熱処理 酵母細胞では起こること、マンノースによって共凝集が阻 害されること、などが明らかとなり、酵母表層のマンナン 糖鎖と乳酸菌表層のレクチン様タンパク質との相互作用を 機序とする細胞接着によって形成されていることが強く示 唆された ${ }^{14,18)}$ 。さらに、酵母のマンナン生合成に関与する 遺伝子の久損株を用いた解析により、乳酸菌 ML11-11 は 酵母マンナンの分岐鎖構造を認識して細胞接着することを 明らかにした ${ }^{19)}$

こうした結果に加えて、乳酸菌 ML11-11 と清酒用酵母 の野生型である協会 7 号酵母やその泡なし变異株の協会 701 号などとの相互作用を解析する過程で、泡なし変異株 の方が野生型株に比べて乳酸菌 ML11-11 との共凝集性や 複合バイオフィルム形成性が高いことを見出した。清酒酵 母の野生型細胞の表層には清酒醸造時の高泡形成に関与す るAwal タンパク質が存在して扔り、泡なし変異株では Awal タンパク質が細胞表層に存在しないことが知られて 


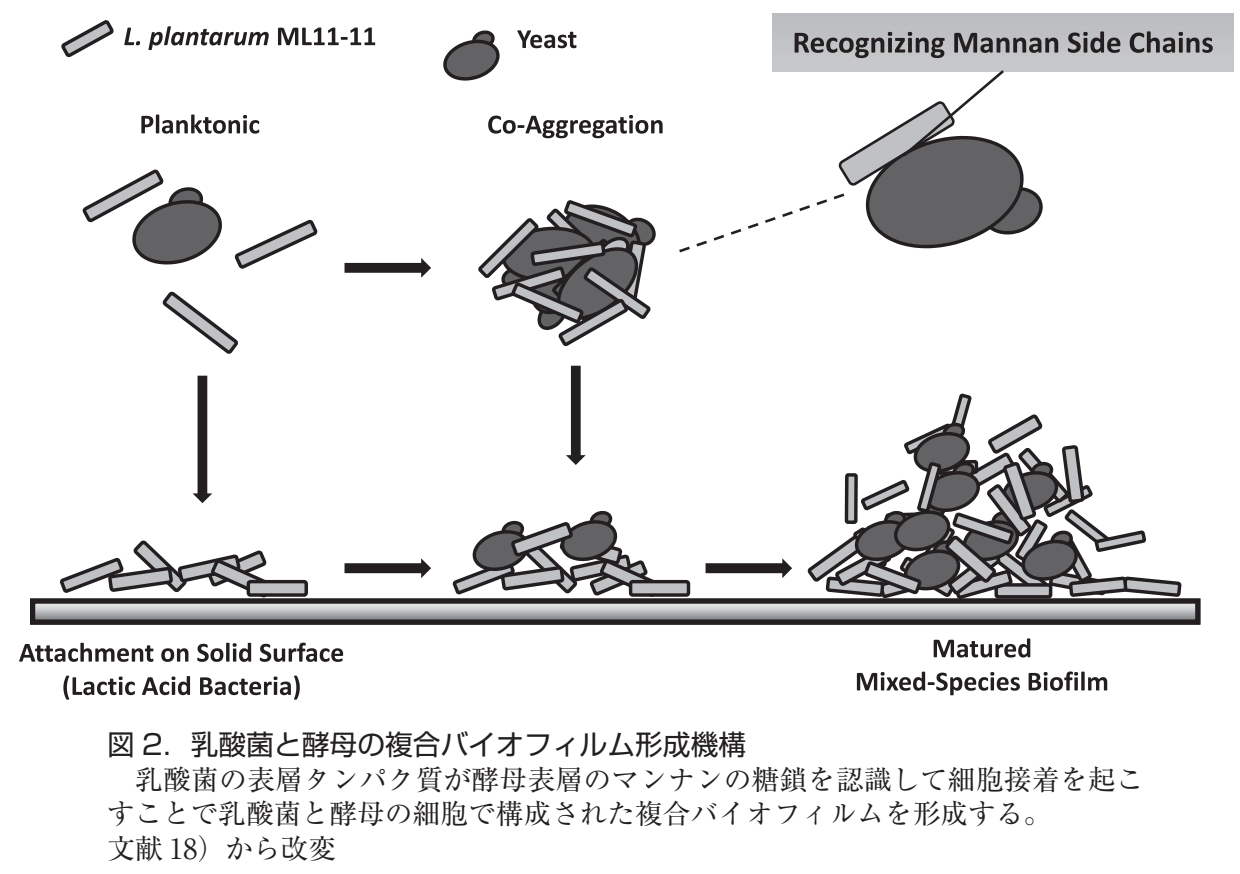

いる。そこでAwal タンパク質をコードする $A W A 1$ 遺伝 子の欠損株やプラスミド上にクローニングした $A W A 1$ 遺 伝子を導入した形質転換体を用いて乳酸菌 ML11-11 との 共凝集性や複合バイフィルム形成性を調べた結果、Awa1 タンパク質によって酵母と乳酸菌の間の細胞接着が阻害さ れていることが明らかになった ${ }^{20)}$ 。

生酛づくりの種母作製過程において醰母と乳酸菌が共存 し、最終的には主発醳酵母 S. cerevisiae が優占化するこ とはよく知られている ${ }^{4,10)}$ 。種母作製の途上で出現する乳 酸菌は乳酸を生成して、グラム除性菌や産膜酵母の上うな 雑菌の生育を抑制し、主発酵醰母が優占化する環境を整え る。そして、その役割を終えると徐々に菌数が低下してい くとされている。ところが、乳酸菌の活動が醸造過程後期 まで衰えない場合には酒の風味に好ましくない影響を及ぼ し腐造となる。乳酸菌と強い相互作用で接着する醳母は、 乳酸菌が付随してくるため、腐造を起こしやすい性質を 持っているのではないかと考えられる。したがって、長年 の優良清酒酵母の選別の過程で、腐造を起こしにくい、す なわち乳酸菌と接着しにくい醅母が選ばれてきた可能性が ある。協会 7 号などの $A W A 1$ 保有株が清酒䣲母として選 定されてきた背景には、乳酸菌と接着しにくく、腐造を起 こしにくい酵母であった、という特性があったのではない か。前述の野生型清酒醅母の Awal タンパク質が乳酸菌 の接着を阻害するという知見は、こうしたことを想起させ るものである。

さて、この酵母・乳酸菌複合バイオフィルムは、酵母を 乳酸菌と共培養するだけでセルロースなどのバイオマスの 担体上に形成させることができ、自律的に再生可能な固定 化菌体として半連続発酵や連続発酵によるエ夕ノール生産 に利用できる。しかも、乳酸菌が共存するため、雑菌污染
に対する耐性を有するなど、優れたロバスト性を有してい た。この共培養系では、乳酸菌が糖を消費して乳酸が生成 するが、生成した乳酸の大部分が醅母によって利用される ため、培地中に蓄積する乳酸の量は比較的少なく、エタノー ル収率の低下は軽微であった ${ }^{15,21)}$ 。

\section{2-3. 乳酸菌と酶酸菌の相互作用}

次に我々は、福山酢より分離した各種の乳酸菌と酢酸菌 の相互作用を、バイオフィルム形成を指標として調べてみ た。乳酸菌と酢酸菌を組み合わせて共培養した結果、800 通り以上の組み合わせの $95 \%$ 以上で酢酸菌のバイオフィ ルム形成が増加することが明らかとなった。そこで、福 山酢から分離した乳酸菌 ML11-11 と酢酸菌 Acetobacter pasteurianus A11-10（以下 A11-10）を選定し、共培養で のバイオフィルム形成を詳細に検討したところ、酢酸菌の バイオフィルムは、いわゆるペリクルとして、気液界面 から上部に顕著に形成され、液内の固体表面に乳酸菌の バイオフィルムが形成されることが確認された ${ }^{22)}$ 。酢酸 菌のペリクル形成は、乳酸菌との共培養時だけでなく、乳 酸菌培養上清や乳酸を培地に添加することによっても促進 されたことから、乳酸菌が産生する乳酸が形成促進因子 と考えられた。さらにピルビン酸も乳酸と同様の効果を 示した ${ }^{22)}$ 。

乳酸菌との共培養や乳酸添加によるペリクル形成促進は ゲノム公開株である A. pasteurianus IFO3283-32でも同 様に認められたことから、酶酸菌に普遍的な現象と考えら れた。なお、酶酸菌 A11-10 と酵母 Y 11-43 の二菌種系と、 これに乳酸菌 ML11-11 を加えた三菌種の共培養系におけ る酢酸発醳を比較した結果、グルコースを炭素源とする培 地を用いた場合、三菌種系での酢酸生成が有意に高いこと 
が明らかとなった。こうした乳酸菌共存下の酶酸発酵の促 進は、酢酸菌ペリクル形成の促進に伴う発醉効率の向上に 起因すると考えられた ${ }^{23)}$ 。

これらの結果をもとに、福山酶の発酵過程におけるバイ オフィルムの役割を推定した（図 3 )。素焼きの壸の内面 や蒸米の表面に乳酸菌と酵母の複合バイオフィルムが形成 され、麹のアミラーゼによって米のデンプンから生成され たグルコースを乳酸やエタノールに変換する。一方、培養 液の気液界面には、乳酸菌が生成した乳酸を利用して、酢 酸菌のバイオフィルム（ペリクル）が旺盛に形成され、エ タノールを効率的に酶酸に変換する。このように福山酢の 壷の中では、二種類のバイオフィルムの共役によって、糖 類から酢酸への代謝がきわめて効率的に起こっているもの と考えられる ${ }^{24)}$ 。

\section{3. 福山酢にみる微生物の共生と進化}

\section{3-1. 栄養獲得のための共生}

前述のように、福山酢では酵母、乳酸菌、酥酸菌の三菌 種が共存しており、バイオフィルム形成という相互作用を 通じて発酵成立に寄与していると考えられる。そこで、こ れら三菌種が抢互いにどのような共生関係にあるのかをさ らに検討することにした。微生物が共生する目的としては 栄養獲得およびストレス回避が考えられる。

まず栄養獲得に関する共生関係についてみてみよう。酵 母と乳酸菌の間には、乳酸菌が要求するアミノ酸やビ夕 ミンを酵母が供給することで共生関係が成立する可能性 がある ${ }^{10)}$ 。我々は乳酸菌 ML11-11 と酵母 S. cerevisiae BY4741 を最少培地（田村・角田培地 ${ }^{25}$ ) 中で除菌フィル

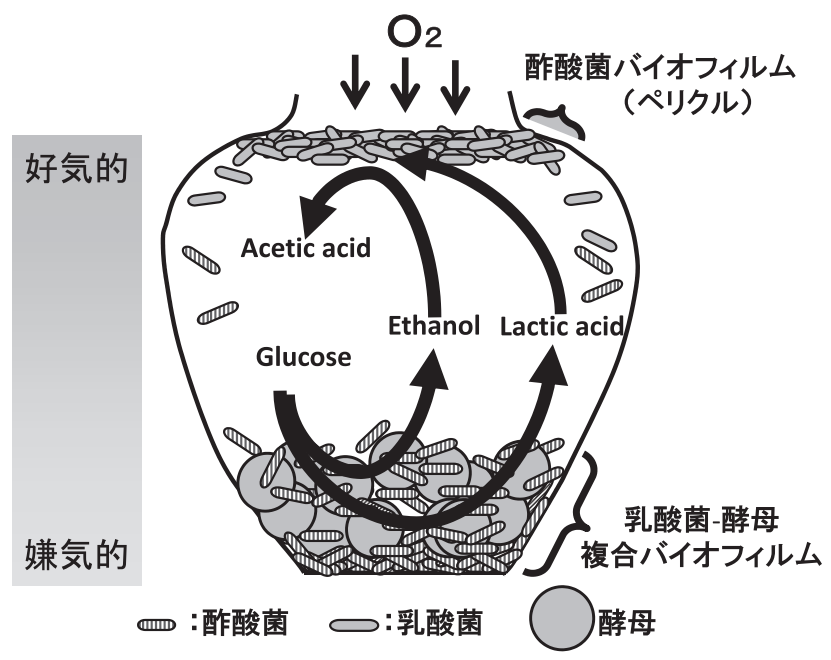

図 3. 福山酢の発酵システムとバイオフィルム

壶の底部に乳酸菌と酵母の細胞で構成された複合バイオフィル ムが形成され、培養液の上部には酢酸菌の細胞で構成された単独 バイオフィルム (ペリクル) を形成。乳酸菌と酵母によって生成 した乳酸やアルコールを利用して酢酸菌が効率的に酥酸を生成す る。文献 24）から改変
ターを隔てて培養してみた。その結果、乳酸菌 ML11-11 の生育に必要なアミノ酸やビタミンを酔母 BY4741 が提 供していることを示す結果を得た ${ }^{26)}$ 。この結果は乳酸菌 ML11-11 が酵母を片利共生的に利用していることを意味 する。一方、乳酸菌の産生する乳酸は、前述のように酵母 の炭素源としても利用され、酶酸菌のペリクル形成を促進 することから、酵母や䤀酸菌は乳酸菌の恩恵を得ているこ とになる。

ここで、乳酸による酢酸菌のペリクル形成促進現象に関 して考察する。ペリクルを形成している酢酸菌の培養系は 不均一である。そのため、酢酸菌の生菌数を正確に把握す ることは困難だが、我々の調べた限りでは、乳酸は培養系 の生菌数を増加させるのではなく、ペリクル量を特異的に 増大させるようである。ペリクル量増大の原因としては多 糖合成の充進が考えられる ${ }^{27)}$ 。 KEGG で公開されている 乳酸菌 L. plantarum WCFS1 の代謝マップをみると、乳 酸菌では解糖系による嫌気的糖代謝が主要経路であり、ペ ントースリン酸経路はあまり使われていないようである。 また、好気的な TCA 回路は持っていない ${ }^{28)}$ 。

一方、酢酸菌 A. pasteurianus IFO3283-32 の代謝マッ プによると、A. pasteurianus には解糖系の中核を担うホ スホフルクトキナーゼをコードする遺伝子が存在せず、解 糖系が途中で切断されている (図 4) ${ }^{28)}$ 。そのため、酢酸 菌がグルコースを代謝する場合、ピルビン酸はペントース リン酸経路経由でしか供給されず、ピルビン酸がエネル ギー代謝の律速物質となっていると考えられる。ところ が、乳酸菌との共培養時には、乳酸菌が生成する乳酸を酢 酸菌がピルビン酸源として利用可能となるため、TCA サ イクルへの炭素代謝の流れが円滑になり、その結果ペン トースリン酸経路の代謝フラックスに余裕ができて多糖合 成が活性化されると考えられる。さらに乳酸菌が大量に供 給する乳酸を利用して、ピルビン酸を経由し、ペントース リン酸経路への炭素代謝の逆行が起こって多糖合成が活性 化したことも考えられる（図 $4 、 5$ )。このように乳酸菌 と酶酸菌は共存することで代謝経路を互いに補い合って、 糖代謝を活発化させている。福山酢の発酵過程でも、乳酸 菌と酢酸菌が乳酸の受け渡しを介して代謝系を分担して糖 代謝を行っていると考えられる（図 3 )。乳酸菌と酢酸菌 の共生系に抢ける代謝経路の共有化は、いわば「共生代謝 “Symbiotic Metabolism”」とも呼ぶべき現象で、伝統発䤉 の過程だけでなく自然界においても、乳酸菌や酶酸菌の優 占化に役立っていると考えられる。

次に、酵母と酢酸菌の関係を考えてみる。良く知られて いるように、酵母の生産するエタノールは酢酸菌によって 活発に利用される。この関係も一種の共生関係とみること ができる。酶酸菌にとって、酵母によって生産されるエ夕 ノールはまたとないエネルギー源であり、酥母にとって酢 酸菌が過剩に蓄積するエタノールを消費してくれることは ストレス軽減にもなり好ましいことであろう。 

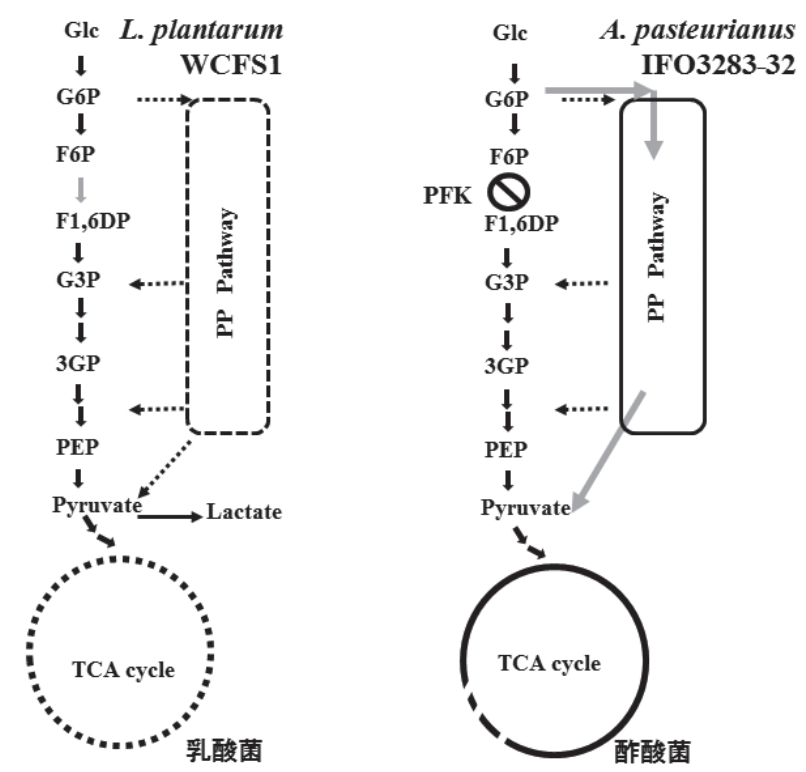

図 4. 乳酸菌及び酢酸菌の単独培養時の糖代謝

酢酸菌はホスホフルクトキナーゼがないため単独培養では糖り ン酸化経路でしかグルコースを利用できない。乳酸菌の単独培養 では TCA 回路がないため乳酸が多量生成する。( $\mathrm{KEGG}^{28)}$ の図 を改変)

ところで、多糖類やタンパク質などの高分子栄養物は、 分解酵素を持たない酵母や酢酸菌は利用できないが、乳 酸菌は分解酵素を持っているため利用できる。したがっ て、乳酸菌との共培養系では、乳酸菌の力を借りること で、酵母や酢酸菌も高分子栄養物を利用可能になると考え られる ${ }^{10)}$ 。

また、L. plantarum など一部の乳酸菌はピリミジンや アルギニンの合成に必要なカルバモイルリン酸が欠そして おり、生育に高濃度の二酸化炭素を必要とするが、この二 酸化炭素を酵母が供給している例が報告されている ${ }^{29)}$ 。 以上の栄養獲得に関する共生関係を図 6 に表した。この他 にも、三菌種の間にはまだ未解明の栄養物が共生因子とし て㗢いている可能性があるのではないかと考え、我々は共 培養系のメタボローム解析も試みている ${ }^{30)}$ 。

\section{3-2. ストレス回避のための共生}

ストレスの回避や軽減をどう図るかは生物の生存戦略と してきわめて重要である。ストレス因子としては、生息環 境の酸素濃度、 $\mathrm{pH}$ 、浸透圧、さらには他の微生物との競 合や原生動物などの捕食者からのストレスなど様々なもの がある。

これらの中で、福山酢製造過程におけるストレス因子と してまず考えられるのが酸化ストレスである。乳酸菌は通 性嫌気性菌で酸素分圧の比較的低い環境であれば生育可能 だが、呼吸鎖やカタラーゼを持っていないため酸素の豊富 な環境はストレスになる。酵母も乳酸菌ほどではないが高 濃度酸素の環境は好まない。一方、酢酸菌は絶対好気性で

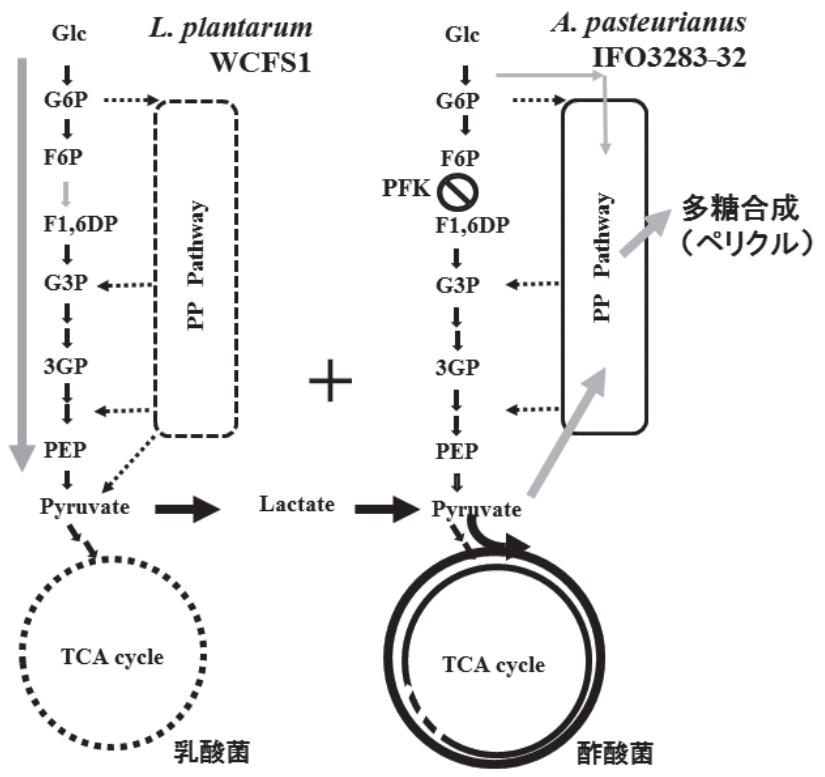

図 5. 酢酸菌と乳酸菌の複合培養時の糖代謝 (Symbiotic metabolism)

酢酸菌と乳酸菌を共培養すると、酢酸菌は乳酸菌が生成した乳 酸をピルビン酸源として利用可能になるため、TCA 回路や糖リ ン酸回路の炭素フラックスが改善され、糖新生による多糖生産が 促進されてペリクル形成が活性化すると推察。

培養液表面にペリクルを形成して酸素を活発に消費する。 その結果、ペリクルに覆われた培養液内部は酸化ストレス に弱い酵母や乳酸菌の生育に好ましい嫌気的な環境になる (図 3 )。このように、乳酸菌や酵母にとって酢酸菌と共生 することは、酸化ストレスを回避する上で大きな利点が ある。

次に低 $\mathrm{pH}$ における酸性ストレスについてみてみよう。 乳酸菌、酵母、酢酸菌はいずれも低 $\mathrm{pH}$ 環境に適合性があ り、これら 3 種の微生物が自然界で共存し得る最も重要な 因子と考えられる。しかしながら、乳酸菌の乳酸生産に 伴う急激な $\mathrm{pH}$ の低下は細胞質の酸性化を招き、乳酸菌自 身にとってだけでなく、酢酸菌や酵母にとっても大きなス トレスとなる。ところが、三種共存系では乳酸菌が生産す る乳酸を酢酸菌や酵母が資化することによって、生息環境 の $\mathrm{pH}$ の低下が緩和されると考えられる。実際に乳酸菌単 独培養系と、乳酸菌と酵母の複合培養系での糖消費を比 較してみると、乳酸菌単独系では培養液 $\mathrm{pH}$ の低下が著し く、多くの糖が消費されずに残されるのに対し、酵母が共 存する複合系では酵母が乳酸を消費するため、乳酸の過剩 な蓄積が起こらず、 $\mathrm{pH}$ 低下が緩和された結果、菌の活性 が維持されて、糖が完全に消費されるということが確認さ れた ${ }^{15,20)}$ 。

さらに、自然界では生息環境に侵入してくる雑菌との競 合も大きなストレスとなる。酵母・乳酸菌二菌種共存系に 大腸菌や枯草菌をモデル雑菌として接種してみると、高い 雑菌排除能を示すことが明らかとなった ${ }^{15,20)}$ 。酵母と乳酸 菌に、さらに酢酸菌が加わった三菌種共存系では、酢酸菌 


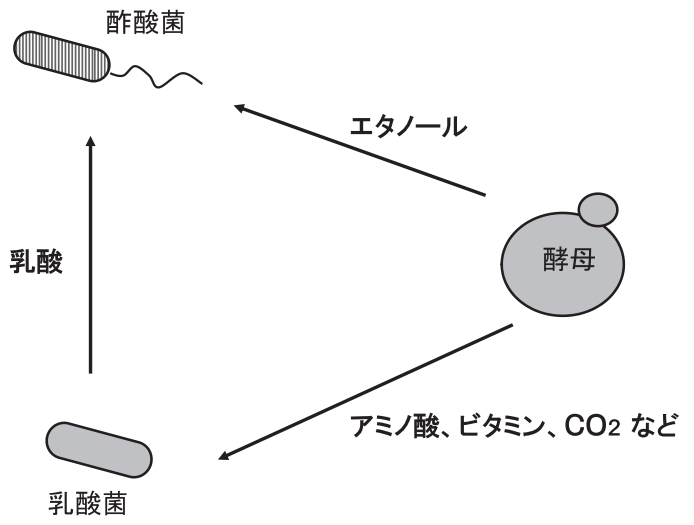

図 6. 酵母・乳酸菌・酢酸菌間の栄養に関する共生関係

の形成するペリクルや酢酸によって雑菌排除能がさらに高 まることが考えられる。これらのことから、酵母・乳酸菌・ 酢酸菌三菌種共存系は様々なストレスに抵抗性を持った共 生系であると考えられる。

以上の考察をもとに、福山酢における三菌種共生による ストレス回避の機序を図 7 に示した。このように、模擬的 自然環境とも言える福山酢においては、酵母、乳酸菌、酢 酸菌の巧みな共生関係が成立している。こうした共生関係 の解析をさらに深めることによって、それぞれの微生物が 互いに関係し合いながら進化を遂げてきた道筋が見えてく るのではないだろうか。

\section{3-3．福山酢からみえてくる発酵微生物の進化}

以上の福山酢にみられる三菌種共生系に関する知見をも とに、酵母、乳酸菌、酢酸菌がどのように進化してきたか を、いささか大胆ではあるが推理してみたい。

三菌種は酸性環境に適応している点で共通点があり、進 化の過程でニッチでの共存が起こり、パートナーとしての 道を歩み始めたと考えられる。共存の結果、前述したよう に、飢餓やストレスから回避することが可能になった。共 生によって、アミノ酸、ビタミンなど栄養物の授受や、酸 素、低 $\mathrm{pH}$ 、外敵侵入など生存を劦かすストレスへの対応 が可能になった。これに加えて、共生によって炭水化物代 謝における役割分担が構築され、炭素源を独占できるよう になり、乳酸菌、酵母、酢酸菌からなる微生物コミュニティ が確立されたのではないだろうか。このような共生系での 役割分担が確立すると、ある微生物にとって単独生活では 不可欠な機能であっても、共生生活では他の微生物が補っ てくれるので、なくても良いものがでてくる。こうした共 生生活にとって不可欠でない機能は、進化の過程で退化し て失われる運命にあったのであろう。

福山酢における共生関係から読み解くと、例えば、酵母 との共生でアミノ酸やビタミンなどの供給を得られるよう になった乳酸菌は、一部のアミノ酸やビタミンの生合成経 路を失った。また乳酸菌との共生で、乳酸菌から乳酸の供

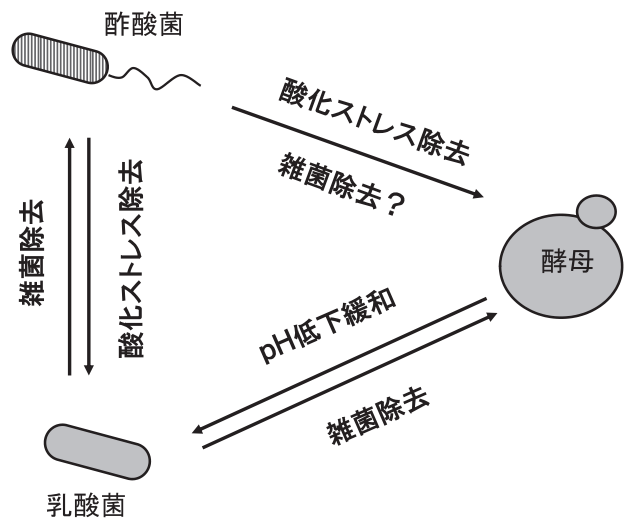

図 7. 酵母・乳酸菌・酢酸菌間のストレスに関する共生関係

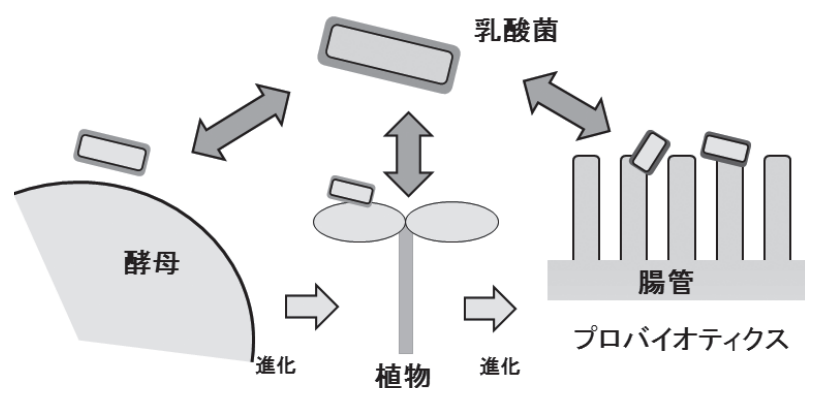

図 8. 乳酸菌の進化過程における宿主の変遷

乳酸菌はその表層タンパク質を介して他生物に接着する寄生生 物としての生き方を選び進化を遂げた。進化の過程で寄生の相手 を酵母から植物へ、さらには動物へと乗り換えたと推察。

給を受けることが可能になった酢酸菌は、解糖系の一部を 失い、酸化発酵に特化するためぺリクル形成するように なった。一方、乳酸菌は酢酸菌との共生により嫌気環境が 保証されたため、酸化ストレス対応機構を失い、TCA サ イクルなどの好気的代謝機構の多くを失った。このように、 栄養物の下面 (内部) を住処とする乳酸菌、酵母と上面 (気 液界面）を住処とする酢酸菌が住み分け、炭水化物代謝系 やアミノ酸、ビタミンの生合成系を補完し合って、強固な 生存システムを構築し、炭素源を独占可能となった。こう した進化の過程で、酵母は乳酸菌や酢酸菌から遺伝子を取 り込み好気、嫌気のいずれにも対応できるよう進化したと いうことも考えられる。

前述のように、乳酸菌 ML11-11 は酵母に対し特異な接 着性を示すが、酵母に接着するということが乳酸菌にとっ てどんなメリットがあるのか考察してみたい。乳酸菌と酵 母が離れて存在している場合は、互いの相互作用が弱く、 また行動を共にするのが難しいが、乳酸菌と酵母が接着し ている場合には行動を共にすることが可能になり、至近距 離から栄養物を受け取ることができるなど大きなメリット がある。乳酸菌にとって厳しい自然環境を生き抜くには、 酵母に接着していることが断然有利だったに違いない。こ うした乳酸菌の姿をみると、乳酸菌は進化の過程で酵母に 接着して寄生するという道を選んだのではないかとも考え 
られる。また、接着することでひょっとすると遺伝物質の 授受が起こり、乳酸菌と酵母が共進化してきた可能性も ある。

さらに視野を乳酸菌と植物細胞や動物細胞の関係にまで 広げてみると、酵母との接着から植物細胞との接着、さら には動物細胞（消化管上皮細胞）との接着へと、乳酸菌 は寄生する相手を選びながら接着することによって生存 領域を拡大していった様子をうかがい知ることができる (図 8)。

\section{参 考 文 献}

1) Wood BJB (1981) The yeast/Lactobacillus interaction; a study in stability, p.137-150, Mixed culture fermentations, ed. by Bushell ME and Slater JH, Academic Press, London.

2) 伊藤僘敏, 岡田早苗 (1996) 乳酸菌と他の微生物の共生, p.270-274, 乳酸菌の化学と技術, 日本乳酸菌研集談会編, 学会出版センター, 東京.

3) 岡田早苗 (2010) 乳酸菌の自然界での分布, p.10-15, 乳酸 菌とビフィズス菌のサイエンス, 日本乳酸菌学会編, 京都大 学学術出版会, 京都.

4）岡田早苗（1997）酵母と共棲する乳酸菌, p.66-75, 酵母か らのチャレンジ, 田村學造, 野白喜久雄, 秋山裕一, 小泉武 夫編，技報堂出版，東京.

5）小㠃道雄（2004）発醅食品に打ける乳酸菌の共存と共生, p.184-197, 乳酸発酵の新しい系譜, 小㠃道雄, 佐藤英一編, 中央法規出版, 東京.

6）谷村和八郎（2001）アジアの発酵食品事典, 樹村房, 東京.

7）発醰ハンドブック（2001）財団法人バイオインダストリー協 会発酵と代謝研究会編, 共立出版, 東京.

8) Wood BJB (1998) Microbiology of fermented foods, Blackie Academic \& Professional, London.

9）小嵪道雄（1999）乳酸菌の共生. 日本醸造協会誌 $94: 261$.

10) Furukawa S, Watanabe T, Toyama H, Morinaga Y (2013) Significance of microbial symbiotic coexistence in traditional fermentation. J Biosci Bioeng 116: 533-539.

11）食物と健康の科学シリーズ酢の機能と科学（2012）酢酸菌研 究会編, 朝倉書店, 東京.

12）柳田藤治（1990）衂酢一酢造りの原点を探る。化学と生物 $28: 271-276$.

13) Furukawa S, Yoshida K, Ogihara H, Yamasaki M, Morinaga Y (2010) Mixed-species biofilm formation by direct cell-cell contact between brewing yeasts and lactic acid bacteria. Biosci Biotechnol Biochem 74: 2316-2319.

14) Furukawa S, Nojima N, Nozaka S, Hirayama S, Satoh A, et al. (2012) Mutants of Lactobacillus plantarum ML11-11 deficient in $\mathrm{co}^{-}$aggregation with yeast exhibited reduced activities of mixed-species biofilm formation. Biosci Biotechnol Biochem 76: 326-330.

15）森永康, 古川壮一（2013）酵母 - 乳酸菌複合バイオフィルム の特性と利用. 月刊 BIOINDUSTRY $30: 49-57$.

16) Furukawa $S$, Isomae $R$, Tsuchiya N, Hirayama $S$, Yamagishi A, et al. (2015) Screening of lactic acid bacteria that can form mixed-species biofilm with Saccharomyces cerevisiae. Biosci Biotechnol Biochem 79: 681-686.

17）山岸明日香, 古川壮一, 荻原博和, 森永康（2014）伝統発酵 食品より分離したLeuconostoc 属乳酸菌と出芽酵母によるバ イオフィルム形成, 日本乳酸菌学会 2014 年度秋期セミナー・ 酢酸菌研究会第 6 回研究集会合同シンポジウム講演要旨集.
以上、福山酷からみえてくる発酵微生物の進化について、 大胆に考察してきた。この仮説が妥当なものかどうかを検 証するには、今後さらに詳細な研究が必要だが、我々は伝 統発酔における微生物共生関係を解析することで、発酵微 生物の進化の過程を探るという新しい研究の方向性が見え てきたのではないかと考えている。

\section{追 記}

著者の一人、古川壮一先生は 2015 年 3 月 1 日に 41 歳で 急逝されました。ここに謹んで哀悼の意を表します。

18) Furukawa S, Nojima N, Yoshida K, Hirayama S, Ogihara $\mathrm{H}$, et al. (2011) The importance of inter-species cell-cell coaggregation between Lactobacillus plantarum ML11-11 and Saccharomyces cerevisiae BY4741 in mixed-species biofilm formation. Biosci Biotechnol Biochem 75: 1430-1434.

19) Hirayama S, Furukawa S, Ogihara H, Morinaga Y (2011) Yeast mannan structure necessary for $\mathrm{co}^{-}$aggregation with Lactobacillus plantarum ML11-11. Biochem. Biophys Res Commun 419: 652-655.

20) Hirayama S, Shimizu M, Tsuchiya N, Furukawa S, Watanabe D, et al. (2015) Awalp on the cell surface of sake yeast inhibits biofilm formation and the co-aggregation between sake yeasts and Lactobacillus plantarum ML11-11. J Biosci Bioeng 119: 532-537.

21) Abe A, Furukawa S, Watanabe S, Morinaga Y (2013) Yeasts and lactic acid bacteria mixed-specie biofilm formation is a promising cell immobilization technology for ethanol fermentation. Appl Biochem Biotechnol 171: 72-79.

22）古川壮一, 平山悟, 深瀬栄, 荻原博和, 森永康 (2011) 酵母, 乳酸菌および酰酸菌の複合バイオフィルム形成とその利用。 生物工学会誌 $89: 478-481$.

23) 東垂水彩乃, 増田裕明, 古川壮一,森永康 (2015) Acetobacterpasteurianus, Lactobacillus plantarum おうひび Saccharomyces cerevisiae の 3 菌種複合培養による酢酸発酵, 日本農芸化学会大会講演要旨集.

24）古川壮一，阿部侑，深瀬栄，平山悟，荻原博和，他（2012） 多菌種複合バイオフィルムを利用した物質生産. 日本醸造協 会誌 $107: 292-299$.

25）田村學造, 角田俊直, 桐村二郎，宮澤滋（1952）乳酸菌によ るアミノ酸定量法（その 1 ）乳酸菌のアミノ酸要求並びにア ミノ酸標準曲線の作成. 日本農芸化学会誌 $26: 464-470$.

26）牧大剛, 古川壮一, 森永康（2015）酵母と酵母接着性乳酸菌 の共生関倸. 日本農芸化学会大会講演要旨集.

27) Deeraksa A, Moonmangmee S, Toyama H, Yamada M, Adachi O, et al. (2005) Characterization and spontaneous mutation of a novel gene, polE, involved in pellicle formation in Acetobacter tropicalis SKU1100. Microbiology 151: 41114120.

28) KEGG: Kyoto Encyclopedia of Genes and Genomes, http:// www.kegg.jp/

29) Bringel F, Hubert, JC (2003) Extent of Genetic Lesions of the Arginine and Pyrimidine Biosynthetic Pathways in Lactobacillus plantarum, L. paraplantarum, L. pentosus, and L. casei: Prevalence of CO2-Dependent Auxotrophs and Characterization of Deficient arg Genes in L. plantarum. Appl Environ Microbiol 69: 2674-2683.

30）平山悟, 古川壮一, 森永康（2014）酵母との複合がバイオフィ ルム形成能を有する乳酸菌ゲノムシーケンス及びポストゲノ 厶解析. 日本農芸化学会 大会講演要旨集. 


\title{
Symbiosis and evolution of microorganisms indicated in a traditional fermentation
}

\section{Yasushi Morinaga, Satoru Hirayama and Soichi Furukawa}

\author{
Department of Food Bioscience and Biotechnology, \\ College of Bioresource Sciences, Nihon University
}

\begin{abstract}
Fukuyama pot vinegar is known as traditional Japanese rice vinegar. In the fermentation process of Fukuyama pot vinegar, fungi, yeast, lactic acid bacteria and acetic acid bacteria are involved. During this process, three types of fermentation, namely saccharification, anaerobic alcohol fermentation and aerobic acetic acid fermentation proceed autonomously, sequentially and partly in parallel. This is one of the most primitive fermentation process developed in East Asia and is analogous to carbohydrate metabolism occurred in nature. In order to elucidate inter-species interactions of microbes in this process, we isolated microbes from the brewing samples of the Fukuyama pot vinegar process and investigated the biofilm formation of lactic acid bacteria and yeasts or lactic acid and acetic acid bacteria under $\mathrm{co}^{-}$culture conditions. In the result, we found a unique mixed-species biofilm formation by lactic acid bacteria and yeasts on solid-liquid interface in a bottom of culturing vessel and also found a significant increase of acetic acid bacteria biofilm (pellicle) on liquid surface of culture broth in the co-existence of lactic acid bacteria. In further studies, we realized that the co-existent system of these three microbes is an ingenious symbiotic system to cope with risks such as nutritional deficiency, oxidation stress, and invasion of other bacteria and so on. In this review, we outline properties of symbiotic system of these fermentation microbes from our recent studies and discuss about aspects on evolution of these fermentation microbes.
\end{abstract}

